\title{
Technical efficiency of meat sheep production systems in Spain
}

\author{
J.P. Pérez ${ }^{a}$, J.M. Gil ${ }^{b,}$, I. Sierra ${ }^{a}$ \\ ${ }^{a}$ Dpto. Producción Animal y Ciencia de los Alimentos. Facultad de Veterinaria. Universidad de \\ Zaragoza, Miguel Servet, 177, 50013-Zaragoza, Spain \\ ${ }^{b}$ CREDA-UPC-IRTA. Edifici ESAB - Campus del Baix Llobregat \\ Av. del Canal Olimpic, s/n, 08860-Castelldefels (Barcelona, Spain)
}

\begin{abstract}
The technical efficiency of sheep results in one of the most important sheep producing regions in Spain has been assessed. The methodology is based on a survey from representative farms (in terms of the existing alternative production systems) within the region. Results indicate that the best farms, in terms of technical efficiency, are obtained by extreme situations: either by extensive and well-managed farms, without pens and one lambing per year (lower production but well adapted to the seasonality of prices and more reduced costs), or by well managed farms with prolific ewes. Thus, maximum efficiency is determined not so much by the production system as by the technical and economic management to accommodate the specific circumstances of each farm.
\end{abstract}

Key words: Sheep production, Spain, Technical efficiency, Frontier production functions

\footnotetext{
${ }^{*}$ Corresponding author. Tel.: +34-935521210; fax: +34-935521121; E-mail address: chema.gil@upc.edu
} 


\section{Technical efficiency of meat sheep production systems in Spain}

\section{Introduction}

Sheep production in Aragón ${ }^{1}$ is important not only from the social, economic and biological points of view, but also for cultural and ecological aspects (Sierra, 2000). In this region, 3.5 million lambs are fattened per year in more than 8,000 sheep farms. Approximately $80 \%$ of the farms are in less-favoured areas and are more dependent on European Union (EU) subsidies (Ashworth et al., 2000),

Early studies about the sheep sector in Aragón merely aimed to describe the production model and its economic performance (gross margins) and to analyse the impact of EU subsidies on these parameters (Sierra, 1977; and Manrique and Sáez, 1984; among others). However, in the context of the progressive liberalization of world markets and future cuts in subsidies (especially after the incorporation of Eastern European countries), an evaluation of the efficiency and profitability of sheep farms is necessary in order to assess future viability.

Using more or less similar data sets than those considered in previous studies, the aim of this paper is to apply econometric models to determine to what extent sheep farms are efficient when allocating input quantities to obtain the final output. Additionally, sheep farms are divided in two main groups according to their efficiency (above and below mean sample values) and are characterized taking into account their

\footnotetext{
${ }^{1}$ Aragón is an autonomous region in northern Spain, with a surface area of $47.616 \mathrm{~km}^{2}$ and a semiarid climate.
} 
1 lamb meat productivity as well as their cost structure, in order to identify main factors

2 affecting meat sheep farms efficiency

3 The methodology used is based on the estimation of a frontier production function

4 following Greene's (1980) procedure. It consists of estimating a production function by

5 Ordinary Least Squares (OLS) and displacing the constant term until all the errors were

6 negative, except one, which was zero. Battese and Coelli (1988), Neff et al. (1993) and

7 Murúa and Albisu (1993), among others, provide good examples of this approach.

8 In these types of models it is considered that the main causes of inefficiencies are

9 represented by the error term but ignore the real possibility that the efficiency can be

10 influenced by factors that are out of control of the producers, such as the climate,

11 diseases, the unavailability of resources in a specific period, etc. As a result, in recent

12 years, researchers have adopted the concept of stochastic frontier production in which the inefficiency is considered as only one part of the random disturbance. This approach was developed by Aigner et al. (1977) and applied by Coelli (1988), Bravo-Bureta and Rieger (1990); and Tzouvelekas et al. (2002), among others. estimated and, in a second step, residuals from the estimated equation are analysed in terms of some farm characteristics. Then, we isolate the error component that cannot be controlled by the farmer. Although the paper refers to a specific region, it aims to provide a useful tool, which can be applied elsewhere, to better understand the performance of the lamb sector in a specific region or country.

The rest of the paper is structured as follows. In Section 2 the data and the econometric tools are described. Main results are presented and discussed in Section 3. Finally, some concluding remarks about the implications of the findings for the sheep sector are outlined. 
1

\section{Material and methods}

Data were obtained from a survey of 49 farms from Aragón, specialized in meat production. An important difference among farms was the sheep breed used. The most common was Rasa Aragonesa, a rustic and extensively used breed autochthonous to the region and therefore competes for pasture in less favoured areas (Sierra, 2000). Other observed breeds were more prolific (in terms of more lambs per birth) or belong to other genotypes that greatly increase production in more intensive systems. The questionnaire included several technical and economic data from the year 2000, since the fieldwork was carried out in spring 2001. Before carrying out the survey we designed a pilot questionnaire that was completed by eight farms to determine whether they could easily provide the requested information. Finally, we tested whether the final questionnaire was coherent and consistent.

The main economic data requested was related to sales and main expenses (feed, labour, etc.). We also asked about interests paid on capital invested as well as the depreciation of installations, equipment and livestock in order to calculate the Farm Income (instead of the traditional gross margin). We also took into account the family workforce.

As mentioned in the introduction, in this paper, a Cobb-Douglas Frontier Production Function is estimated using Greene's (1980) approach assuming that the error terms are non-positive (farms can not produce above the frontier), independent and identically distributed. Likewise, we assumed that explanatory variables are independent of the error term. The following explanatory variables have been considered:

- Feed Costs (FC), which involves the supplementary feed for the sheep, the pasture cost as well as the feed for lambs. 
- Depreciation of capital (DC) invested, including fixed capital (installations) and the existing credits at the time of the study.

- Labour (L)), which includes both an approximation of the cost of the family workforce as well as salaries, including possible seasonal and temporary contracts. All data used are measured in monetary terms, which are generally more precise than information measured in physical units.

\section{Results and discussion}

Table 1 (first column) summarises the mean values and coefficients of variation of the main technical and economic variables (euros/sheep/year), without considering EU subsidies. As can be observed, the labour productivity (number of sheep per work unit) as well as the other two technical variables considered (the number of lambs born per ewe and the number of lambs sold per ewe) showed a lower variability than most of the different cost items considered in Table 1. Moreover, as total sales variability is also relatively low $(22 \%)$ in relation to the different cost items, the performance of meat sheep farms in Aragón (measured by Farm Income) exhibited a large variability $(100 \%)$.

(Insert Table 1)

Further analyses suggested that the main out-farm expenses were feed and labour (taking into account both the family workforce and salaries). Again, these costs showed the largest variability, specially the feed costs in pastures, which is a good indicator of the existing diversity in the feed systems used in Aragón as well as the difficulty of rationing them.

A novelty in this study is that it specifically considers interests from credits and depreciation of installations and equipment (in euros per ewe per year). In these cases, 
1 the variability found is representative of the existing diversity in sheep farms

2 (installations are fully depreciated or are new, no as opposed to major debt, etc). The

3 average Farm Income was negative, indicating that the sector (at least in Aragón) is very dependent on EU subsidies.

The new intensive systems have helped to increase production (Stefanou and

6 Saxena, 1983) but also have increased costs, making the problem even worse. Many

7 farmers have not considered the efficiency of several production factors, specially when

8 they try to improve results using the same local breed (Rasa Aragonesa). In fact,

9 although some authors (Valls, 1983) have shown that combining the ability of the mentioned local breed to be fertile during the seasonal anoestrus period (provided that

$$
\begin{aligned}
& \hat{\mathrm{P}}=\underset{(-0.24)}{-0.26}+\underset{(10.83)}{0.76 \mathrm{FC}}+\underset{0.29}{0} \mathrm{~L}+\underset{0.02}{0} \mathrm{DC} \\
& \overline{\mathrm{R}}^{2}=0.86 \quad \mathrm{~F}_{\mathrm{AV}}=100.65 \quad \mathrm{~B}-\mathrm{P}=3.61
\end{aligned}
$$

where all variables are expressed in logarithms, $\hat{\mathrm{P}}$ is the estimated farm output, $\mathrm{F}_{\mathrm{AV}}$ is the statistic to test the joint significance of all explanatory variables, and B-P is the Breusch-Pagan test for heteroscedasticity

As can be observed, the production function was correctly specified. The value of the B-P statistic was under the critical value at the $5 \%$ level of significance (7.81), and 
1 the value of the Adjusted $\mathrm{R}^{2}$ was relatively high (0.86). All the variables had the

2 expected signs and their coefficients were statistically significant at the 5\% level. Given

3 that the variables are measured in logarithms, the coefficients were interpreted as

4 elasticities. For example, increasing the feed cost by $1 \%$ would increase output value by

$5 \quad 0.76 \%$.

6 From the economic point of view, the results indicate that the sheep sector in

7 Aragón is more intensive in labour that in capital. Moreover, the sum of the coefficients

8 of the explanatory variables was unity, implying that the sheep sector is characterised by

9 constant returns of scale (if all inputs increased on the same proportion the output will

10 increase in the same percentage). In any case, this hypothesis was tested, and the value

11 of the corresponding statistic was 1.07 , which was well under the critical value at the

$125 \%$ level of significance (3.84), indicating that the constant returns to scale hypothesis

13 could not be rejected. After estimating the average production function we added to the

14 constant (-0.26) the maximum positive residual (in our case 0.43 ) in order to displace

the estimated function to obtain the frontier production function $\left(\mathrm{P}^{*}\right)$. In other words, $\mathrm{P}^{*}$

16 represents the maximum level of output that could be attained for a given combination

17 of inputs.

From the frontier production function we have calculated the average level of inefficiency in the sheep sector in Aragón using the measure proposed by Timmer (1971). This method relates, for each farm, the real output produced $\left(\mathrm{P}_{\mathrm{i}}\right)$ and the potential output that could be obtained in the frontier $\left(\mathrm{P}{ }_{\mathrm{i}}\right)$, using the actual combination of inputs. Taking into account the functional form adopted for the frontier production function, the Timmer's measure of Technical Efficiency is given by:

$$
\text { Technical Efficiency } y_{i}=P_{i} / P_{i} \quad i=1 \ldots 49 .
$$


2 0.66. In other words, these farms could improve production by $34 \%$. As a final step in

Results indicate that the average technical efficiency of sheep farms in Aragón is our analysis we have tried to assess main characteristics of most efficient farms. To achieve this objective, farms were divided into two main groups: above or below the average efficiency (0.66). For each group we have calculated the average values of the main economic variables in terms of euro/sheep/year (columns 2 to 5 in Table 1). The more inefficient farms (38.7\% of the sample) were those with higher production costs and relatively little rationalization of labour in relation to the number of head produced and/or the actual needs at specific moments during the production process. The most inefficient farms showed the lower labour productivity (335 head/ work unit) and with lesser reproductive intensification (1.08 lambs sold per ewe per year). These farms are paying higher interests, partly due to the important investments made in installations and/or the herd that are either too expensive or not adjusted to the farm size. In some cases, important investments are due to the desire to increase the number of head in order to adopt better handling practices.

Finally, the most inefficient farms show the lowest Farm Income values. In fact, farms with a technical efficiency between 0.39 and 0.50 exhibit an average sales value of $59.2 €$ per ewe per year, compared with a value of $74.83 €$ in the most efficient farms. However, it seems that facilities are not used to capacity, as labour and feed costs are relatively high. As a result, the Farm Income of inefficient farms is lowest $(-50.33 €)$ making them highly dependent on EU subsidies.

With respect to the eight most efficient farms, one third had costs and expenses that were adjusted to their possibilities and capacity, especially one farm which practiced one mating per year, did not use hormonal treatments, did not keep animals in pens and the degree of capitalization was average. Accordingly, the traditional extensive system 
1 can provide excellent results under adequate management, correct planning and

2 coordinating all the existing resources throughout the productive year (reproduction,

3 feed, labour, installations, etc.) (Sierra, 1994). In this case the technical efficiency was

4 0.97, which is comparable with the farm with the maximum efficiency (1.00), a well

5 managed farm that uses prolific breeds.

6 On the other hand, prolific breeds did not seem to guarantee a high level of

7 efficiency. Moreover, farms with a prolific genetic base should be managed correctly.

8 Feed needs to be rationed, investments should be optimised, in terms of a long term

9 planning of depreciation and interest, and farm size has to be defined avoiding excess

10 capacity. None of these farms reach the optimum production level and economic results

11 are only average (efficiency index around 0.57-0.60). With adequate herd handling and

12 management skills, efficiency levels could be increased considerably.

\section{Conclusions}

Using statistical tools to analyse the efficiency of sheep farms, this paper has shown that the optimal Farm Income can be obtained by rationalising main inputs in the production process, adapting them to real needs and availability. The best results, in terms of efficiency, have been obtained by extreme farms, either extensive, wellmanaged farms, without pens and one lambing per year (less final production but low costs and a correct orientation towards the seasonality lamb prices), or well managed prolific farms. Thus, maximum efficiency is determined not so much by the production system as by the technical and economic management to accommodate the specific circumstances of each farm. 
1

2

3

4

5

6

7

\section{References}

Aigner, D.J., Lovell, C.A.K., Schmidt, P., 1977. Formulation and estimation of stochastic frontier production function models. J. Econometrics, 5, 21-38.

Ashworth, S, Northen J., Boutonnet J.F., Gil J.M., Ben Kaabia M., 2000. An evaluation of the Common Organization of the markets in the sheep and goat meat sector. (www.europa.eu.int/comm/agriculture/eval/reports/sheep/index en.htm, 17-02-2003).

Battese, G.E., Coelli, T.J., 1988. Predicting firm level technical efficiencies with a generalised frontier production function and panel data. J. Econometrics, 38, 387-399.

Bravo-Bureta, B.E., Rieger, L., 1990. Alternative production frontier methodologies and dairy farm efficiencies. J. Agr. Econ. 41, 215-226.

Coelli, T.J., 1988. Estimation of frontier production function. A guide to the computer program "Frontier Version 2.0". Working Paper in Econometrics and Applied Statistics, 34. Department of Econometrics. University of New-England, Armidale.

Greene, W.H., 1980. On the estimation of a flexible frontier production model. J. Econometrics, $13,101-115$.

Manrique, E., Sáez, E., 1984. Cálculo y análisis de los costes de producción en una muestra de explotaciones ovinas (Analysis of production costs from a sample of sheep farms). IX Jornadas Científicas de la S.E.O.C. 531-555.

Murúa, J.R., Albisu, L.M., 1993. Eficiencia técnica en la producción porcina de Aragón (Technical efficiency of pig production in Aragón). Invest. Agr.: Econ. 8, 239-252.

Neff, D.L., García, P., Nelson, C.H., 1993. Technical efficiency: a comparison of production frontier methods. J. Agr. Econ. 44, 479-489.

Sierra, I., 1977. Economía de las empresas ovinas (The economics of sheep farms). Plenary Paper, II Jornadas de la Sociedad Española de Ovinotecnia. Mérida. Actas: 157-177.

Sierra, I., 1994. Los recursos alimenticios y planificación reproductivo-productiva según el sistema de explotación ovina. (Feed resources and reproductive-productive planning in sheep production systems). OVIS. Aula Vet. 33, 9-29.

Sierra, I., 2000. La ganadería aragonesa y sus productos de calidad (The Aragonian livestock sector and its quality products). CAI. 100 (Caja de Ahorros de la Inmaculada), 130 pp.

Stefanou, S.E., Saxena, S., 1983. Education, experience and allocative efficiency: a dual approach. Am. J. Agr. Econ. 65, 829-831.

Timmer, C.P., 1971. Using a probabilistic frontier production function to measure technical efficiency. J. Polit. Econ. 79, 776-794.

Tzouvelekas, V., Pantzios, C.J., Fotopoulus, C., 2002. Empirical evidence of technical efficiency levels in Greek organic and conventional farms. Agr. Econ. Rev. 3, 49-60.

Valls, M., 1983. Frequent lambing of sheep flocks in Spain: productivity and management consequences. Lives. Pro. Sci, 10, 49-58. 
1 Table 1. Main economic characteristics of sheep farms in Aragón (sample average

2 values and for different groups according to its technical efficiency. (Euro/sheep/year)

\begin{tabular}{|c|c|c|c|c|c|c|}
\hline & \multirow{2}{*}{$\begin{array}{l}\text { Sample } \\
\text { average } \\
\text { values }^{1}\end{array}$} & \multicolumn{2}{|c|}{$\begin{array}{c}\text { Under average } \\
\text { technical efficiency }\end{array}$} & \multicolumn{3}{|c|}{$\begin{array}{c}\text { Above average technical } \\
\text { efficiency }^{2}\end{array}$} \\
\hline & & $0.39-0.50$ & $0.51-0.65$ & $0.66-0.70$ & $0.71-0.80$ & $0.81-1.00$ \\
\hline Sheep per working unit (number) & $438(37.5)$ & 335 & 454 & 501 & 459 & 419 \\
\hline Lambs born /ewe /year (number) & $1.68(18.8)$ & 1.46 & 1.78 & 1.79 & 1.70 & 1.66 \\
\hline Lambs sold/ewe/year (number) & $1.38(25.5)$ & 1.08 & 1.48 & 1.53 & 1.45 & 1.32 \\
\hline \multicolumn{7}{|c|}{ BALANCE SHEET } \\
\hline A. TOTAL SALES & $71.66(22.1)$ & 59.2 & 68.89 & 75.22 & 77.12 & 74.83 \\
\hline B.1. Total cost of feed & $40.69(29.9)$ & 45.47 & 46.23 & 41.74 & 38.86 & 28.13 \\
\hline B.1.1. Sheep feed costs & $19.44(51.4)$ & 25.00 & 22.47 & 16.56 & 19.85 & 11.86 \\
\hline B.1.2. Pastures & $10.01(76.7)$ & 9.38 & 11.20 & 12.88 & 10.49 & 10.53 \\
\hline B.1.3: Feed for lambs & $11.24(39.9)$ & 11.09 & 12.56 & 12.3 & 8.52 & 5.74 \\
\hline B.2. Sanitary costs & $1.75(61.6)$ & 2.24 & 1.71 & 1.26 & 2.13 & 1.16 \\
\hline B.3. Labour & $28.54(46.3)$ & 42.03 & 27.3 & 22.33 & 25.87 & 27.6 \\
\hline B.4. Other costs & $7.5(42.2)$ & 5.02 & 8.35 & 5.68 & 11.0 & 6.83 \\
\hline B. TOTAL COSTS & $78.48(24.8)$ & 94.76 & 83.59 & 71.01 & 77.86 & 63.72 \\
\hline C. Depreciation & $3.98(98.5)$ & 4.8 & 4.36 & 6.62 & 2.4 & 2.76 \\
\hline D. Interest & $11.07(52.1)$ & 9.98 & 12.73 & 15.17 & 8.49 & 10.3 \\
\hline E. MARGIN (A-B) & $-6.82(314.1)$ & -35.56 & -14.70 & 4.21 & -0.74 & 11.11 \\
\hline F. FARM INCOME (E-C-D) & $-21.89(100.1)$ & -50.33 & -31.79 & -17.57 & -11.64 & -1.94 \\
\hline
\end{tabular}

$3{ }^{1}$ Values in parentheses correspond to coefficients of variation $(\%)$

$4 \quad{ }^{2}$ Average technical efficiency $=0.66$ 